\title{
Mezi výzkumem a praxí: Pasteurův kvadrant jako př́ležitost ke změně
}

\section{Michaela Spurná}

Od prvního okamžiku, kdy jsem vstoupila na pole pedagogického výzkumu, jsem si kladla otázku, k čemu vlastně pedagogický výzkum je a komu má vlastně sloužit. Svou první kvalifikační práci (Spurná, 2013) na FF MU jsem proto orientovala na využívání pedagogického výzkumu učiteli. Práce vycházela $\mathrm{z}$ nepř́lilš velkého množství zahraničních empirických studií (např. Ozturk, 2010, 2011) a z textů prof. Průchy (1985; ale i 1993, 1996, 2009, 2013), který problematiku využívání pedagogického výzkumu učiteli u nás explicitně otevřel. ${ }^{1}$ Tehdy, v počátcích, jsem byla přesvědčena, že se jedná o téma, které není dostatečně rozvíjené jak u nás, tak ani $\mathrm{v}$ zahraničí. $\mathrm{V}$ tomto přesvědčení mne utvrzovaly i další dva aspekty.

První aspekt byl popsán již v sedmdesátých letech 20. století Danilovem (1972), který tvrdil, že v pedagogickém výzkumu se dostatečně nerozvíjela ani jedna z metodologií. Ve své době Danilov hovořil o trojí metodologii, a to (1) o metodologii pedago- gického výzkumu jako způsobu získávání pedagogických poznatků, (2) o metodologii výstavby pedagogické teorie, její teoretické základny, soustavy a struktury a (3) o metodologii zavádění pedagogických poznatků do pedagogické praxe. ${ }^{2} \mathrm{~V}$ podstatě dodnes platí, že z uvedených tři metodologií je rozvíjena především jedna, ta výzkumná (způsob získávání pedagogických poznatků). Druhým aspektem byla (a dosud je) metodika hodnocení výsledků pedagogického výzkumu. Ta je, přes některé světlé stránky (jako např. důraz na význam výzkumu pro společnost; Metodika 17+, s. 13), založena na metrikách publikování významných časopiseckých studií, aniž by byl sledován dopad poznatků na praxi. ${ }^{3}$

$\mathrm{Z}$ hlediska rozvoje metodologie přenosu poznatků pedagogického výzkumu do praxe však bylo mé přesvědčení mylné, alespoň co se vývoje v zahraničí týče. Obrat v přesvědčení nastal při tvorbě mé disertační práce (Spurná, 2019), kvůli které jsem musela hluboko proniknout

\footnotetext{
${ }^{1}$ K tématu se později vyjadřovali autoři Gavora (2007), Štech (2009), Mareš (2009), Maňák (2011) či Višňovský, Kašćák a Pupala (2012), kteří problematiku akcentovali spíše z hlediska potřeby praxe založené na dủkazech (evidence-based practice).

${ }^{2}$ Přesné znění: (1) metodologie aspektů výstavby teorie, (2) metodologie podmínek zavádění poznatků do praxe, (3) teorie.

${ }^{3}$ Aniž by byla sledována jejich faktická kvalita či etická zodpovědnost jejich autorů (Knecht, 2014, s. 4).
} 
do zahraničních studií a publikací. A pokud bych měla nyní shrnout, co přesně změnilo mé přesvědčení, byl to především objem a kvalita nabízené literatury. $\mathrm{Z}$ množství prostudované literatury bych dnes ráda poukázala na jednu publikaci, která svou myšlenkou podporuje účel vzniku českého pedagogického výzkumu. $\mathrm{Na}$ počátku 20. století realizovali výzkumy průkopníci jako F. K. Kořistka, O. Kádner, F. Č́áda či V. Př́íhoda, aby mohli objevovat různou povahu pedagogických jevů a tím jim porozumět a současně prrímo inovovat tehdejší výuku ve škole. Podporující myšlenkou takto zamýšleného výzkumu je Pasteurův kvadrant, který popsal Stokes v roce 1997. Pojednává především o smyslu a zaměření výzkumů, tedy i výzkumu pedagogického. Ráda bych tímto však chtěla poukázat i na to, že přenos pedagogického výzkumu do praxe není jen o zvažování jeho využívání učiteli v praxi a směřování veškeré pozornosti na stranu konzumentů. Stokesova myšlenka Pasteurova kvadrantu vtahuje do hry také ty, kdo poznatky pedagogického výzkumu generují, tj. výzkumníky, vědce, akademiky.

\section{STOKES A DEFINOVÁNí \\ Pasteurova kVadrantu}

Po několik desetiletí se uplatňuje paradigma, ${ }^{4}$ že lineární návaznost mezi základním a aplikovaným výzkumem je daná a neodmyslitelná. Toto, pokud to tak nazvu, pravidlo je vyučováno na vysokých školách $\mathrm{v}$ rámci pedagogického (ale i jiného) výzkumu a váží se $\mathrm{k}$ němu formulované cíle a výzkumné otázky, výzkumný design a odběratelé výsledků.

V roce 1997 se v linearitě základního a aplikovaného výzkumu objevila anomálie, která mění nebo může změnit uvažování vědců a výzkumníků (či poskytovatelů finančních prostř̌edků) např́ić vědami, tj. i ve vědách pedagogických. Lineární návaznost základního a aplikovaného výzkumu se Stokes (1997) snažil překonat tím, že u původních typů vyzkumů identifikoval kořeny a druhy vědění, podle nichž rozlišil mezi fundamentálními otázkami a úvahami o jejich využití. Následně vyvodil vztahy mezi jednotlivými typy výzkumů. Zkonstruoval jednoduchou kombinaci typů výzkumů a tím představil jejich hlavní zástupce a s nimi související produkty (tab. 1).

Tab. 1. Kombinace typů výzkumů a jejich možností (zdroj: Trna, 2011; přeloženo autorem)

\begin{tabular}{|c|c|c|}
\hline & \multicolumn{2}{|c|}{ Aplikovaný výzkum inspirovaný úvahami o využití } \\
\hline \multirow{3}{*}{$\begin{array}{l}\text { Základní výzkum } \\
\text { inspirovaný úvahami } \\
\text { o podstatě jevů }\end{array}$} & $\mathrm{NE}$ & ANO \\
\hline & $\begin{array}{c}\text { Bohr } \\
\text { ANO ( čistý základní výzkum) }\end{array}$ & $\begin{array}{c}\text { Pasteur } \\
\text { (aplikací inspirovaný výzkum) }\end{array}$ \\
\hline & $\mathrm{NE}$ - & $\begin{array}{c}\text { Edison } \\
\text { (čistý aplikovaný výzkum) }\end{array}$ \\
\hline
\end{tabular}

${ }^{4}$ V Kuhnovském pojetí. 
V obrázku vidíme základní výzkum realizovaný Nielsem Bohrem, který objevil poznatky o kvantové fyzice (strukturu atomů a jejich záření), za něž získal Nobelovu cenu. Jeho př́nos byl čistě teoretický, s malým dopadem na praxi (Stokes, 1997). Takový výzkum Stokes považuje za čistě základní. Za poznatek z aplikovaného výzkumu považuje Stokes např. Edisonův vynález - žárovku, jež přispěla především běžným lidem, tj. praxi. $V$ tomto ohledu byl Edison motivován objevy pro praktické užití (Tierney \& Holley, 2008, s. 290). Stokes podle zmíněných vědců pojmenoval př́slušné kvadranty, např. Bohrův kvadrant, Edisonův kvadrant. $\mathrm{Na}$ obrázku lze však vidět ještě další dva kvadranty, které leží mezi kvadrantem aplikačním a teoretickým. Trna (2011) ve třetím kvadrantu udělal pomlku, byt Stokes na tomto místě viděl výzkumy, jejichž př́nosem jsou např. taxonomie či klasifikace (např. ornitologická práce J. J. Audubona), a proto lze tento kvadrant nazvat „Audubon“ (Audubonův kvadrant). Výzkum v tomto kvadrantu nerozvijí vědění a není ani účelný pro praxi (Tierney \& Holley, 2008, s. 290), s čímž je možné polemizovat.

Do posledního, pro nás stěžejního kvadrantu Stokes (1997) umístil výzkum realizovaný Pasteurem. Ten pracoval s oběma typy výzkumu současně, a to jak se základním, tak s aplikovaným (Smith et al., 2013, s. 152). Východiskem byla teoretická hypotéza: rostoucí mikroorganismy jsou zodpovědné za zhoršování kvality nápojů. Ověření této hypotézy přispělo k vynálezu pasterizace, což vedlo k jejímu okamžitému využití v praxi. Nejednalo se tedy ani o čistý základní výzkum, ani o čistý aplikovaný výzkum, ani o lineární povahu obou těchto výzkumů (nejprve základní, poté aplikovaný). Takové propojení Stokes (1997) pojmenovává jako dvoudimenzionální konceptuální rovinu a kvadrant nazval jako základní výzkum inspirovaný užitím či aplikací (volně přeloženo z use-inspired basic science).

Striktní rozdělení výzkumů směřující $\mathrm{k}$ vymezení nové a radikální myšlenky v podobě Pasteurova kvadrantu bylo původně zamýšleno především pro prírodní vědy. Nicméně princip generování poznatků prímo prospěšných praxi podle Pasteurova kvadrantu lze analogicky využít i v oblastech společenských věd, konkrétně v oblasti věd pedagogických. Existují autoři, kteří v Pasteurově kvadrantu vidí potenciál. Např́klad Tushman a O'Reilly (2007) $\mathrm{v}$ oblasti ekonomie hovoří o tom, že takový výzkum zkracuje cestu mezi tvůrci a odběrateli výzkumných poznatků a umožňuje užitečně využívat poznatky obou světů. Podobný potenciál spatřují i Burkhardt a Shoenfeld (2003, s. 5) či Biesta (2010, s. 498-499) pro oblast pedagogiky, když hovoří o efektivním a rychlém řešení reálných životních otázek učitelů pomocí výzkumů. Burkhardt a Shoenfeld (2003, s. 7; ale i Brown, 2012) dokonce vyzývají k realizaci většího množství pedagogických výzkumů v oblasti Pasteurova kvadrantu. $\mathrm{V}$ tomto smyslu také autoři hovoří o pákách, tzv. pionýrských institucích, které by poskytovaly důkazy o tom, jak může být pedagogický výzkum převeden do praxe, a to v nejvyšší úrovni kvality. Vedle toho 
Simmons et al. (2005) upozorňují, že takto realizovaný výzkum již existuje. Výzkum, který podpořil současně teorii i praxi, byl realizován v USA. Vědecké poznatky zde posloužily $\mathrm{v}$ politickém koncepčním dokumentu NCLB (No Child Left Behind'), který měl dopad až na samotné žáky.

Dokážu si představit, že takových výzkumů může být větší množství, a to i na úrovni regionálního školství a př́mo v ČR. Je úctyhodné, kolik vědců a výzkumníků v současnosti v závěrech svých výzkumných časopiseckých studií formuluje doporučení pro praxi. Můžeme si klást otázku, co vede autory (často základních) výzkumů k tomu, že takto činí? Bud’ to může být zaprríčiněno intuitivním vnímáním potřeb praxe činit rozhodnutí opřená o výzkumy, nebo je to dáno vnitřní touhou náhodně ovlivňovat praxi bez systematicky řízeného transferu poznatků do praxe, anebo to jen požadují redakce časopisů.

$S$ využitím Pasteurova kvadrantu je možné od počátku tvořit design výzkumu tak, aby byl rigorózní, podle stanovených pravidel a činností (např. pro účely základního výzkumu podporovaného GA ČR), a současně zohledňoval potřeby praxe (Shaffer \& Squire, 2006, s. 1-2). Autoři uvádějí, že s pomocí tohoto kvadrantu by se mohl zlepšit i „zoufalý“ stav pedago- gického výzkumu, který „panuje“ v celém světě. Není totiž novinkou, že pedagogický výzkum je považován za druhořadný. Už v roce 1996 Hargreaves upozorňoval na jeho nepřispívání praxi, nízkou čtenost výzkumných zjišstění a nepropojování roztř́ištěných výzkumů do vědního celku. Burkhardt a Shoenfeld $(2003$, s. 3) přiznávají, že v současnosti má výzkum ve vzdělávání ještě méně respektu, než jak tomu bylo kdysi.

Jinými slovy, využívání Pasteurova kvadrantu umožňuje rekontextualizaci pedagogického výzkumu. Lze hovořit o tzv. novém typu pedagogického výzkumu, jenž propojuje požadavky obou typů výzkumu (Smith et al., 2013, s. 158). Pasteurův kvadrant lze vidět i jako východisko z propasti mezi teorií a praxí či jako východisko řešení požadavku zavádění „evidence-based practice“6 (Tierney \& Holley, 2008; Smith et al., 2013). I Mareš (2009, s. 234-235) upozornil na potřebu pojmenování nového typu výzkumu, který by obecně zvýšil užitečnost pedagogického výzkumu - a Pasteurův kvadrant by v tomto ohledu mohl posloužit.

\section{SHRNUTí}

Stokes (1997) poskytl prostor k uvažování o snadnější cestě pedagogického výzku-

\footnotetext{
${ }^{5} \mathrm{~V}$ pozdějších letech byl však prýstup autorů NCLB kritizován jinými autory jako „tlak bez významu $s$ úsměvnými cíli“" (Fullan, 2010, s. 120)

${ }^{6}$ Celý tento koncept evidence-based practice (dále jen EBP) byl však podroben kritice (Hammersley, 2001). Namísto EBP začaly být navrhovány jiné termíny, jako např. praxe inspirovaná důkazy (evidence-inspired practice) nebo praxe ovlivněná důkazy (evidence-influenced practice; Hammersley, 2013), jimiž měl být přesněji vyjádřen vztah mezi poznatkem a praxí. Současným trendem jsou např. také koncepty jako informace založená na výzkumu, kterou využivají školy (research-based information in education; Dagenais et al., 2012) a informované vzdělávání o důkazech (evidence-informed education; NFER, 2017; Ostinelli, 2016).
} 
mu k praxi, která si však žádá nekonzervativní myšlení. Jedná se o proud základního výzkumu inspirovaného aplikací (teoretického, ale i praktického vědění), který považuji za kvadrant vhodný pro oblast pedagogických věd. Ztotožňuji se s názorem, že jakýkoli produkt pedagogického výzkumu má určitou míru přenositelnosti do praxe. Pokud bychom většinu výzkumů orientovali do kvadrantu (Bohrova) základního výzkumu jen proto, že to např́klad vyžadují některé grantové agentury a metodika hodnocení výsledků výzkumu, tak bychom přirovnávali pedagogický výzkum napŕíklad $\mathrm{k}$ výzkumům oboru teoretické fyziky (astrofyziky). Zde totiž realita o černé díre exis- tuje jen $\mathrm{v}$ představách a $\mathrm{v}$ matematických výpočtech na papíru. Pak si kladu otázku: je pro nás pedagogický jev, který je zkoumán, také jen teoretickou entitou, jako je např. černá díra? Na druhou stranu, na obhajobu „čisté vědy“ založené na lásce a vášni $\mathrm{k}$ vědě uznávám, že Pasteurův kvadrant nabízí určitý prostor pro realizaci výzkumu na objednávku, což odklání vědeckou práci od tradičního pojetí vědy (Ziman, 2003). Nicméně, zvážíme-li chybějící metodologii výstavby pedagogické teorie (dle Danilova, 1972), která by mohla mít za následek nízké odhodlání vědců $\mathrm{k}$ syntéze vědění (Janík, 2010, s. 17), klad’me si otázku, k čemu by měl pedagogický výzkum vlastně přispívat?

\section{Literatura}

Biesta, G. (2010). Why 'what works' still won't work: From evidence-based education to value-based education. Studies in Philosophy and Education, 29(5), 491-503.

Brown, C. (2012). Strategies for facilitating knowledge adoption: How researchers can better influence education policy. Journal of Educational and Social Research, 2(3), 53-66.

Burkhardt, H., \& Schoenfeld, A. H. (2003). Improving educational research: Toward a more useful, more influential, and better-funded enterprise. Educational Researcher, 32(9), 3-14.

Dagenais, C., Lysenko, L., Abrami, P. C., Bernard, R. M., Ramde, J., \& Janosz, M. (2012). Use of research-based information by school practitioners and determinants of use: A review of empirical research. Evidence \& Policy: A Journal of Research, Debate and Practice, 8(3), 285-309.

Danilov, M. A. (1972). Obecná metodologie vědy a speciální metodologie pedagogiky v jejich vzájemných vztazích. Pedagogika, 22(5), 539-555.

Fullan, M. (2010). Positive pressure. In A. Hargreaves, A. Lieberman, M. Fullan \& D. Hopkins, Second international handbook of educational change. Dordrecht: Springer.

Gavora, P. (2007). Vedci a učitelia - vztah dvoch diskurzívnych komunít. Pedagogická revue, 59(2), 115-130.

Hammersley, M. (2001). Some questions about evidence-based practice in education. (Online). Dostupné z www.leeds.ac.uk

Hammersley, M. (2013). The myth of research-based policy and practice. London: Sage.

Hargreaves, D. H. (1996). Teaching as a research-based profession: Possibilities and prospects. London: Teacher Training Agency. 
Janík, T. (2010). Stav a výhledy českého pedagogického výzkumu. Pedagogická orientace, 20(2), 5-22.

Knecht, P. (2014). O strašáku excelentního publikování a predátorských časopisech. Universitas, 47(3), 3-8.

Mareš, J. (2009). Edukace založená na důkazech: inspirace pro pedagogický výzkum i školní praxi. Pedagogika, 59(3), 232-258.

Maňák, J. (2011). K problému teorie a praxe v pedagogice. Pedagogická orientace, 21(3), 257-271.

Metodika 17+. (2017). Metodika hodnoceni výzkumných organizaci a hodnoceni programũ úcelové podpory výzkumu, vývoje a inovací. Praha: Úřad vlády České republiky. Dostupné z https://www.vyzkum.cz

NFER. (2017). The National Foundation for Educational Research. (Online). Dostupné z www.nfer.ac.uk/research/evidence-informed-education/

Ostinelli, G. (2016). The many forms of research-informed practice: A framework for mapping diversity. European Journal of Teacher Edcation, 39(5), 534-549.

Ozturk, M. A. (2010). An exploratory study on measuring educator's attitudes toward educational research. Educational Research and Reviews, 5(12), 758-769.

Ozturk, M. A. (2011). Confirmatory factor analysis of the educators' attitudes toward educational research scale. Educational Sciences: Theory and Practice, 11(2), 737-748.

Průcha, J. (1985). Pedagogický výzkum a pedagogická praxe (Aspekt využitelnosti vědeckých informací). Pedagogika, 35(1), 77-89.

Průcha, J. (1993). Stav a úkoly pedagogického výzkumu v České republice. Pedagogika, 63(4), 371-378.

Průcha, J. (1996). Pedagogická evaluace. Brno: Masarykova univerzita.

Průcha, J. (2009). Využitelnost pedagogického výzkumu. In J. Průcha (Ed.), Pedagogická encyklopedie (s. 824-828). Praha: Portál.

Průcha, J. (2013). Moderni pedagogika. Praha: Portál.

Shaffer, W., D., \& Squire, K. D. (2006). The pasteurization of education. In S. Y. Tettegah \& R. C. Hunter (Eds.), Technology and education: Issues in administration, policy, and applications in K12 schools (sv. 8, s. 43-55). London: Elsevier.

Simmons, P. E., Brunkhorst, H., Lunetta, V., Penick, J., Peterson, J., Pietrucha, B., \& Staver, J. (2005). Developing a research agenda in science education. Journal of Science Education and Technology, 14(2), 239-252.

Smith, G. J., Schmidt, M. M., Edelen-Smith, P. J., \& Cook, B. G. (2013). Pasteur's quadrant as the bridge linking rigor with relevance. Exceptional Children, 79(2), 147-161.

Spurná, M. (2019). Transfer poznatkù z pedagogického výzkumu mezi akademiky a učiteli. (Disertační práce). Brno: Filozofická fakulta Masarykovy univerzity.

Spurná, M. (2013). Pedagogický výzkum očima učitelĩ základních a střednich škol aneb Postoje učiteli k pedagogickému výzkumu. (Magisterská práce). Brno: Filozofická fakulta Masarykovy univerzity. 
Stokes, D. E. (1997). Pasteur's quadrant: Basic science and technological innovation. Washington, D. C.: Brookings Institution Press.

Štech, S. (2009). Edukace založená na důkazech (Magická víra v pedagogickou účinnost?). In V. Šutáková \& J. Ferencová (Eds.), Rozvoj a perspektívy pedagogiky a vzdelávania učitelov (s. 160-163). Prešov: Prešovská univerzita.

Tierney, W. G., \& Holley, K. A. (2008). Inside Pasteur's quadrant: Knowledge production in a profession. Educational Studies, 34(4), 289-297.

Trna, J. (2011). Konstrukční výzkum (design-based research) v př́rodovědných didaktikách. Scientia in educatione, 2(1), 3-14.

Tushman, M., \& O'Reilly III, C. (2007). Research and relevance: Implications of Pasteur's quadrant for doctoral programs and faculty development. Academy of Management Journal, 50(4), 769-774.

Višňovský, E., Kaščák, O., \& Pupala, B. (2012). Pedagogický dualizmus teoretického a praktického: historické pozadie a súčasné ilúzie. Pedagogická orientace, 22(3), 305-335.

Ziman, J. (2003). Akademická a post-akademická věda. Vesmir, 82(1), 47-51.

Mgr. et Mgr. Michaela Spurná, Ph.D.

Pedagogická fakulta Masarykovy univerzity, Katedra geografie;

e-mail: spurna@ped.muni.cz 